\title{
An integrated conceptual approach to study the swordfish (Xiphias gladius Linnaeus, 1758) fishery in the eastern South Pacific
}

\author{
Un enfoque conceptual integrado para el estudio de la pesquería del pez espada (Xiphias gladius \\ Linnaeus, 1758) en el Pacifico Sur Oriental
}
Eleuterio Yáñez ${ }^{1 *}$, Rodrigo Vega ${ }^{2}$, Claudio Silva ${ }^{1}$, Jaime Letelier, ${ }^{1,3}$ Maria Ángela Barbieri ${ }^{1,3}$ and Fernando Espíndola ${ }^{3}$

\author{
${ }^{1}$ Pontificia Universidad Católica de Valparaíso, Casilla 1020, Valparaíso, Chile \\ ${ }^{2}$ Universidad Austral de Chile, Casilla 567, Valdivia, Chile \\ ${ }^{3}$ Instituto de Fomento Pesquero, Casilla 8V, Valparaíso, Chile \\ eyanez@ucv.cl
}

\begin{abstract}
Resumen.- Se analizó la información disponible sobre el entorno ambiental, biológico, ecológico y pesquero asociado a la explotación de la unidad de stock de pez espada (Xiphias gladius) del Pacífico suroriental, además de una revisión bibliográfica de modelos que orientan una aproximación ecosistémica en la administración de pesquerías. De esta forma, se estableció un modelo conceptual que incorpora procesos definidos en tres planos, con tres escalas espaciales (Océano Pacífico, Pacífico suroriental y área de la pesquería) y tres escalas temporales (interanual, estacional e intraestacional). La distribución geográfica, su historia de vida y la actividad migratoria que desarrolla el pez espada, implicaron considerar en el modelo, los estados de huevos y larvas, juveniles y adultos, en las zonas de reproducción, crianza y alimentación de adultos. Sin desconocer la investigación pesquera operativa que se realiza actualmente, el modelo conceptual propone la dimensión de trabajo para el desarrollo de un manejo pesquero integrador.

Palabras clave: Ambiente, explotación, modelo conceptual, hipótesis
\end{abstract}

\section{Introduction}

The eastern South Pacific (ESP) is one of the most productive marine ecosystems on the planet, mostly because nutrient-rich waters are transported by largescale horizontal advection and persistent coastal upwelling (Bernal et al. 1983, Daneri et al. 2000, Blanco et al. 2001). In 2004, for example, of the 86 million tons of fishery resources caught worldwide, 16 million came from the ESP (FAO 2007).

Chile is one of the world's main fishery countries, with around 5 million tons annually in the last 30 years (SERNAPESCA 1978-2007). Pelagic species, including swordfish (Xiphias gladius Linnaeus, 1758), constitute $90 \%$ of the annual catches. Swordfish is a high

\footnotetext{
* Invited author
}

\begin{abstract}
The available environmental, biological, ecological, and fishery data associated with the exploitation of swordfish (Xiphias gladius) in the eastern South Pacific were analyzed and the literature on models aiming at an ecosystem approach to fisheries management was reviewed. The conceptual model set forth in this work incorporates three planes with processes defined on three spatial (Pacific Ocean, eastern South Pacific, fishing area) and three temporal (interannual, seasonal, intraseasonal) scales. Because of the swordfish's geographic distribution, life history, and migratory activity, the model must consider several developmental states (eggs and larvae, juveniles, adults) inhabiting different grounds (spawning, breeding, adult feeding). The conceptual model presented herein, without detracting from current operational fisheries research, suggests what must be done to develop integrated fishery management.
\end{abstract}

Key words: Environment, exploitation, conceptual model, hypothesis

commercial value species that was historically fished for artisanally, but that is now also caught industrially (Oliver 1943, Barbieri et al. 1998, Yáñez et al. 2003a). Although swordfish are reported in the Atlantic, Indian, and Pacific oceans (Beckett 1974, Palko et al. 1981, De Metrio et al. 1989, Barbieri et al. 1990, 1998, Suzuki \& Miyabe 1990, Ward et al. 2000, Barría et al. 2005), adequate knowledge is lacking from an ecosystem perspective that could lead to more integrated fishery management (Olson \& Watters 2003).

The information available on swordfish in the ESP must be integrated in order to elaborate and test working hypotheses on the environment, the resource, its exploitation, and the dependent and related species. In Chile, diverse research initiatives have generated biological, ecological, and fishery data on swordfish since 1987 (Barbieri et al. 1998, Donoso et al. 2003, Yáñez et 
al. 2004, 2006, Barría et al. 2005, 2006). Moreover, environmental information is available on the ESP inhabited by this species (Strub et al. 1998). Nonetheless, no analysis has integrated these different pieces of information. Therefore, the objective of this study was to elaborate a conceptual framework for studying the swordfish fishery in the ESP, identifying spatial and temporal scales related to the species' life cycle and the system's forcings. As result of this, we hope to help establish a foundation on which to construct explanatory models that will lead to an ecosystem approach for managing this fishery.

\section{Data}

\section{Oceanographic data}

The oceanographic processes in the ESP involve diverse related spatial and temporal scales. Regionally, the winds associated with the Pacific Anticyclone (PA) force the surface currents of the subtropical gyre (STG), the west wind drift (WWD), the surface currents along the South American coast, and the seasonality of the upwelling along the coasts of Chile and Peru (Bakun \& Nelson 1991, Rojas $\&$ Silva 1996, Strub et al. 1998). The position and intensity of the subtropical front, which has a regional spatial scale, can be affected by the seasonal movement and intensity of the PA (Stramma et al. 1995, Chaigneau \& Pizarro 2005). Surface and subsurface currents along the coast (on scales of thousands of kilometres) are associated with the northward transport of colder, fresher waters from the subantarctic zone and the fjord and channel systems, whereas warm, salty subtropical and equatorial waters are transported poleward (Silva \& Neshyba 1979, Silva 1983). These currents present intraseasonal, seasonal, and interannual variations and can be modulated by the upwelling along the coast of Chile and Peru (Shaffer et al. 1999, Hormazábal et al. 2002). The uprising of subsurface waters along the coast is led by the interaction of local and large-scale winds that fluctuate from days to weeks (upwelling/downwelling) and on spatial scales of dozens to hundreds of kilometres, that is, mesoscale. These processes generate upwelling fronts and currents along the coast. The structures are instable due to the deformation of the main flow into meander currents that stretch over thousands of kilometres, tongues, filaments, and mesoscale eddies (Leth \& Shaffer 2001); these structures may be the main mechanisms for coastaloceanic transport. In spite of their spatial scales, they last from days to months. To date, an integrated approach has not been taken in the study of eastern boundary systems.

This complex system is associated with low-frequency disturbances (30-60 days) in the austral summer in the form of coastal trapped waves of equatorial origins that appear along the South American coasts. These waves modify the vertical structure of the water column from the coast to dozens of kilometres offshore (Hormazábal et al. 2001). On the interannual scale, ocean processes such as El Niño or La Niña modify the oceanographic conditions of the ESP, deepening the thermocline; generating advection of warmer, salty waters to the southeast; and increasing precipitation and continental run-off (Bello et al. 2004, Maturana et al. 2004). The ecological effects of these events on different species and the trophic layer of the swordfish are not yet clear and raise new questions.

Physical forcings affect marine ecosystems on different spatial-temporal scales and through several mechanisms: on the small-scale are dissipation, turbulent mixing, and diffusion (Mann \& Lazier 1996); on the mesoscale are fronts, eddies, and upwelling (Bakun 1996, Bakun 2006); and on the macroscale are the PA, oceanic gyres, El Niño/La Niña, and thermohaline circulation (Strub et al. 1998, Tomczak \& Godfrey 2001). Regional and local manifestations of this physical forcing can have an instant impact on the biology and ecology of the species or may affect them after a lapse of time (Mann \& Lazier 1996).

\section{Biological fishery data}

The swordfish landings in the ESP were relatively low from 1945 to 1986 and were mainly made by Peru; 1950 was an exceptional year, with 6,000 tons. The first catches declared in Japan in 1974, on the other hand, were less than 3,000 tons. The landings began to increase as of 1986, reaching 14,000 tons in 2004, with noteworthy landings by Chile and, more recently, by Spain (Hinton et al. 2005, Barría et al. 2006).

Off the coasts of Chile, swordfish are found between $18^{\circ} 21^{\prime} \mathrm{S}$ and $40^{\circ} \mathrm{S}$, associated with sea surface temperatures (SST) of $13^{\circ} \mathrm{C}$ to $24^{\circ} \mathrm{C}$ (Yáñez et al. 1996 , Donoso et al. 2003). The Chilean longline fleet operates principally between $22^{\circ} \mathrm{S}$ and $39^{\circ} \mathrm{S}$, and between 120 and 800 nautical miles from the coast; artisanal fishing is more coastal, although incursions are made into the areas around the Juan Fernández Archipelago (Barbieri et al. 1998, Barría et al. 2006).

First studies to define stock units of swordfish show at least two groups in the Pacific: in the first, genetically similar individuals are found off Chile, Ecuador, and Mexico and, in the second, off Hawaii and Australia (Sakagawa \& Bell 1980, Sosa \& Shimizu 1991, Reeb et al. 2000). More recently, Alvarado Bremer et al. (2004) reviewed the published genetic studies of swordfish populations in the Pacific Ocean. They noted that in general, levels of population structuring in the Pacific 
Ocean are extremely low, compared to other basins. It was concluded that additional analyses with larger samples sizes and additional genetic markers were needed to resolve the population structure of swordfish in the Pacific Ocean. Finally, Alvarado Bremer et al. (2006) published findings on stock structure indicating that there are significant genetic differences between stocks of the north and south eastern Pacific, Hawaii and Australia (southwest Pacific).

Swordfish larvae are associated with waters over $24^{\circ} \mathrm{C}$ (Kume \& Joseph 1969). They have found throughout the geographical areas where adults spawn, and they were abundant over a broad region in the Pacific bounded by latitudes $35^{\circ} \mathrm{N}$ and $25^{\circ} \mathrm{S}$ (Grall et al. 1983). Japanese studies of larval distributions from the 1950s-80s (Nishikawa et al. 1985) provide some indication of likely spawning locations in the Pacific, although spatial and temporal coverage in the South Pacific is patchy. The juveniles, although more abundant in tropical and subtropical waters, migrate to higher latitudes as they mature (Matsumoto \& Kazama 1974). Swordfish concentrate in areas with abundant prey, commonly along frontal zones, where the ocean currents or water masses intercept, creating turbulence and marked gradients of SST and salinity (Sakagawa 1989).

Kume \& Joseph (1969) found $24^{\circ} \mathrm{C}$ to be the lower limit of swordfish spawning, a highly seasonal activity that occurs during certain periods of the year and at higher latitudes when the SST exceeds the limit. In the central part of the eastern Pacific Ocean, spawning occurs in spring and summer, whereas, in the western South Pacific, it takes place in summer and throughout the entire year in equatorial waters. Zárate (1997) studied the reproductive cycle of swordfish in the ESP, performing a histological study of the gonads to determine the states of sexual maturity. The average length at sexual maturity was estimated to be $152 \mathrm{~cm}$ lower jaw-fork length for males and $165 \mathrm{~cm}$ for females. Fertilization is external and probably involves the mating of one male and one female (Palko et al. 1981).

Swordfish food items have been studied by, amongst others, Bigelow \& Schroedel (1953), Tibbo et al. (1961), Scott \& Tibbo (1968), Palko et al. (1981), Stillwell \& Kohler (1985), Moreira (1990), Hernández-García (1995), and Chancollon et al. (2006). The scant studies off Chile have largely qualitative results, as in the stomach content study of Barbieri et al. (1998); low sample sizes (Ibáñez et al. 2004, Castillo et al. 2007), or are part of broader studies (Donoso et al. 2003, Yáñez et al. 2004, 2006). Nonetheless, Yáñez et al. (2004) found that, in Cordillera de Nazca off northern Chile, the trophic spectrum of swordfish consists of three groups: molluscs, fishes, and crustaceans. Although cephalopods are the most important item, they are less so in summer and winter and, in fact, fish consumption is more important in winter.

Studies of by-catch are scarce for Chile, with only isolated information available (Acuña et al. 2002). Weidner \& Serrano (1997) indicate that the fauna associated with the swordfish fishery consist of a low percentage of tunas and that sharks are the most common group in the catches. According to Yáñez et al. (2004), catches made in Cordillera de Nazca include rays (Myliobatis chilensis), blue shark (Prionace glauca), albacore (Thunnus alalunga), yellowfin tuna (Thunnus albacares), and jumbo squid (Dosidicus gigas). Lessknown species are also caught that must play a role in the swordfish rearing habitat, requiring adequate identification. A global vision of the by-catch from the swordfish fishery in the oceanic zone surrounding Easter Island can be found in Vega et al. (2009).

\section{Conceptual models}

The effects of the climate on top predators such as swordfish are a growing concern given the 'top-down' effects that fishing could have on the ecosystem (Maury \& Lehodey 2005). Environmental variability affects the abundance and distribution of phytoplankton on several scales, which could have important 'bottom-up' effects on grazing species and, later, on the abundance and distribution of top predators. The simultaneous study of 'bottom-up' and 'top-down' effects on open-ocean pelagic ecosystems requires developing new methodological approaches and appropriate models. Environmental variability can influence biological and ecological processes on different time scales. The model presented by Yáñez et al. (2003a) for the relationships between catches, fishing effort, and temperature could indicate how environmental changes would affect the abundance and/ or availability of swordfish exploited by Chilean fleets (artisanal and industrial).

The oceanographic processes that affect the swordfish act on different spatial and temporal scales; these scales form continuums ranging from a few hours to centuries and from centimetres to thousands of kilometres (Haury et al. 1978, Bernal 1990). Perry et al. (2000) propose that fish catchability in commercial and research fishing fluctuates on diverse spatial and temporal scales, reflecting changes in the physical and biological environments. Hence, we propose a conceptual diagram incorporating the characteristic temporal (from days to centuries) and spatial (from 1 to $10,000 \mathrm{~km}$ ) scales of the physical, biological, and fishery processes and activities. 
Chávez et al. (2002) study the impacts of the 1997 1998 El Niño off central California and define a conceptual model of the associated ecosystem changes. The model describes, on the interannual scale, the relationships established between resource abundance and distribution in its different developmental stages and the temperature, salinity, chlorophyll, sea level, and zooplankton, amongst other variables. Blanco et al. (2002) examine the hydrographic conditions off northern Chile during La Niña and El Niño in 1996-1998. Moreover, Chávez et al. (2003) analyze long-term (50 years) changes in anchoveta and sardine associated with large changes in the environmental conditions of the Pacific Ocean. The conceptual model refers to the variability of ecosystem indicators and changes in the regime on a multidecade scale.

Bertrand et al. (2004) propose an integrated context of factors that occur on different spatial-temporal scales (from days to decades and from local to ocean-wide) and should be considered when interpreting the effect of El Niño events on pelagic fish populations. Yáñez et al. $(2005,2007)$ adapt an integrated conceptual model of different local and large-scale phenomena that affect the marine environment and the distribution of the main pelagic resources off northern Chile.

Perry \& Ommer (2003) propose that the changes in the marine ecosystem are driven by three general processes: (1) natural environmental forcings (e.g. climate), (2) human-induced forcings (e.g. fishing, habitat decline, pollution), and (3) biological processes (e.g. denso-dependent mechanisms, predator-prey relationships). Because of the limited understanding of the scales of impacts on the ecosystems along with the human capacity to interfere in natural systems through technology and economic means result in fundamental difficulties when attempting to understand the reciprocal interactions between human beings and the marine ecosystem. These difficulties include the availability of adequate methodologies and the identification of different analytical scales. It is essential to determine how to combine scales of analysis from the natural and social sciences in order to understand the impact of natural systems on humans and vice versa. Furthermore, processes can propagate or cross scales, such that events on one scale have consequences for the processes on another scale (larger or smaller).

\section{Material and methods}

The study area is located between $10^{\circ} \mathrm{S}$ and $45^{\circ} \mathrm{S}$ and from the South American coast to $120^{\circ} \mathrm{W}$ (Fig. 1). These limits consider the distribution of long-line fleets in the region (Hinton et al. 2005, Vega et al. 2009), and the available climate, oceanographic, and geomorphological data (Rojas \& Silva 1996, Smith \& Sandwell 1997, Chaigneau \& Pizarro 2005, amongst others). The model of the swordfish system considers several life cycle phases (egg-larva, juvenile, adult) and distribution areas (spawning grounds around Easter Island, rearing grounds in part of the area around Cordillera de Nazca, and feeding grounds from the coast of Chile to $800 \mathrm{~nm}$ and between $24^{\circ}$ and $40^{\circ} \mathrm{S}$ ). The ecosystems inhabited by swordfish over the course of their life cycle are characterized by abiotic and biotic components. First we studied the data to determine which elements to include, their scales, and the level of interaction between these. This analysis allowed us to structure the model, define its temporal and spatial scales, and incorporate the system's forcings. Then we associated the population and community dynamics with the fishery and the environment, taking into consideration the data mentioned above (see Data).

Following the authors mentioned previously (see Data), the swordfish ecosystem model uses a spatialtemporal scale diagram that is a useful tool for conceptualizing, integrating, and exploring the relationships of the elements involved. It has been used, for example, to identify the physical processes that could influence the biological processes of fishery resources (e.g. feeding, vertical migration) (Perry et al. 2000). These interscale comparisons present analytical challenges, as they attempt to understand specific behaviour and identify the underlying processes (Perry \& Ommer 2003).

The data on oceanographic, biological, and fishery variability in the eastern boundary ecosystems of the Pacific, along with analyses of similar conceptual models, allow the adaptation of an integrated model for the different local and large-scale phenomena that affect the marine environment of the ESP and the dynamics of swordfish during the different stages of its life cycle (Fig. $2)$. The model covers three planes: (1) the physical environment, (2) swordfish biology, and (3) the fishery. The physical environment includes three forcings associated with spatial-temporal combinations: the ENSO cycle (interannual-Pacific Ocean scale), the annual solar radiation cycle (seasonal-ESP scale), and mesoscale phenomena (intraseasonal-swordfish fishery off Chile scale). Likewise, the biology plane includes three groups of elements that encompass processes susceptible to being affected by forcings from the physical environment: the swordfish stock, the migratory circuit, and feeding. Finally, on the fishery plane, two large groups of elements are identified whose spatial-temporal limits are more diffuse but nonetheless present a hierarchical organization; the interannual-Pacific Ocean and seasonal-ESP scales consist of the economy, fleet activities (fishing effort), 


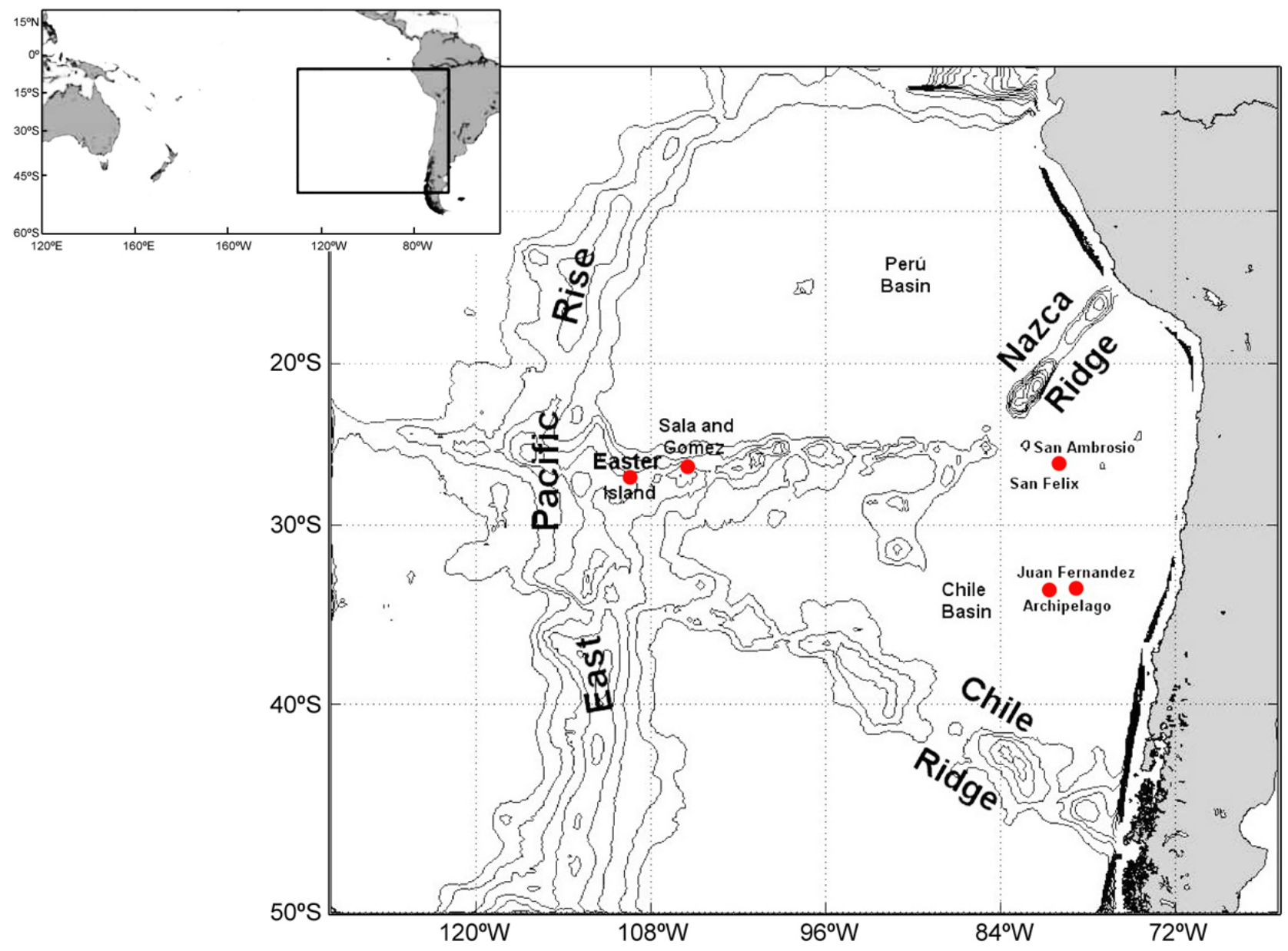

Figure 1

Bottom topography of the eastern South Pacific, including Chile's oceanic islands. The contours indicate, from the outside in, the depths from 3,500 to $1,000 \mathrm{~m}$ at intervals of $200 \mathrm{~m}$. These contours include the trench along the coast of Chile (Smith \& Sandwell 1997)

Batimetría del Pacifico sudeste, incluyendo las Islas Oceánicas de Chile. Los contornos señalan desde afuera hacia dentro las profundidades entre 3.500 a $1.000 \mathrm{~m}$ con un intervalo de $200 \mathrm{~m}$. Estos contornos incluyen la fosa a lo largo de la costa de Chile (Smith \& Sandwell 1997)

resource administration, and social aspects (e.g. employment), whereas the intraseasonal-fishery zone scale consists mainly of fishing effort in terms of fishing trips and sets. The model allows us to relate processes within one plane as well as on different spatial-temporal scales, such as between planes on similar scales.

\section{Results and discussion}

\section{Model}

In the model, swordfish vulnerability and catchability are associated with environmental fluctuations (Podestá et al. 1993, Bigelow et al. 1999, Sedberry \& Loefer 2001,
Seki et al. 2002). Therefore, variations in the catch rates are influenced by physical variability through a biological response of the species and the pelagic community on similar spatial-temporal scales. If these dynamics change in scale, the impact of the forcing could be reflected in aspects such as the economy, fishery administration, and employment. As for the physical environmental forcing on the individual, the local swordfish groups and stock, on different spatial-temporal scales, affect the biology and ecology of the resource, with consequences for the fishery in the form of altered catch rates. In turn, variations in the fishery (e.g. fishing intensity, national and international administration, economic cycles, etc.) affect the swordfish 

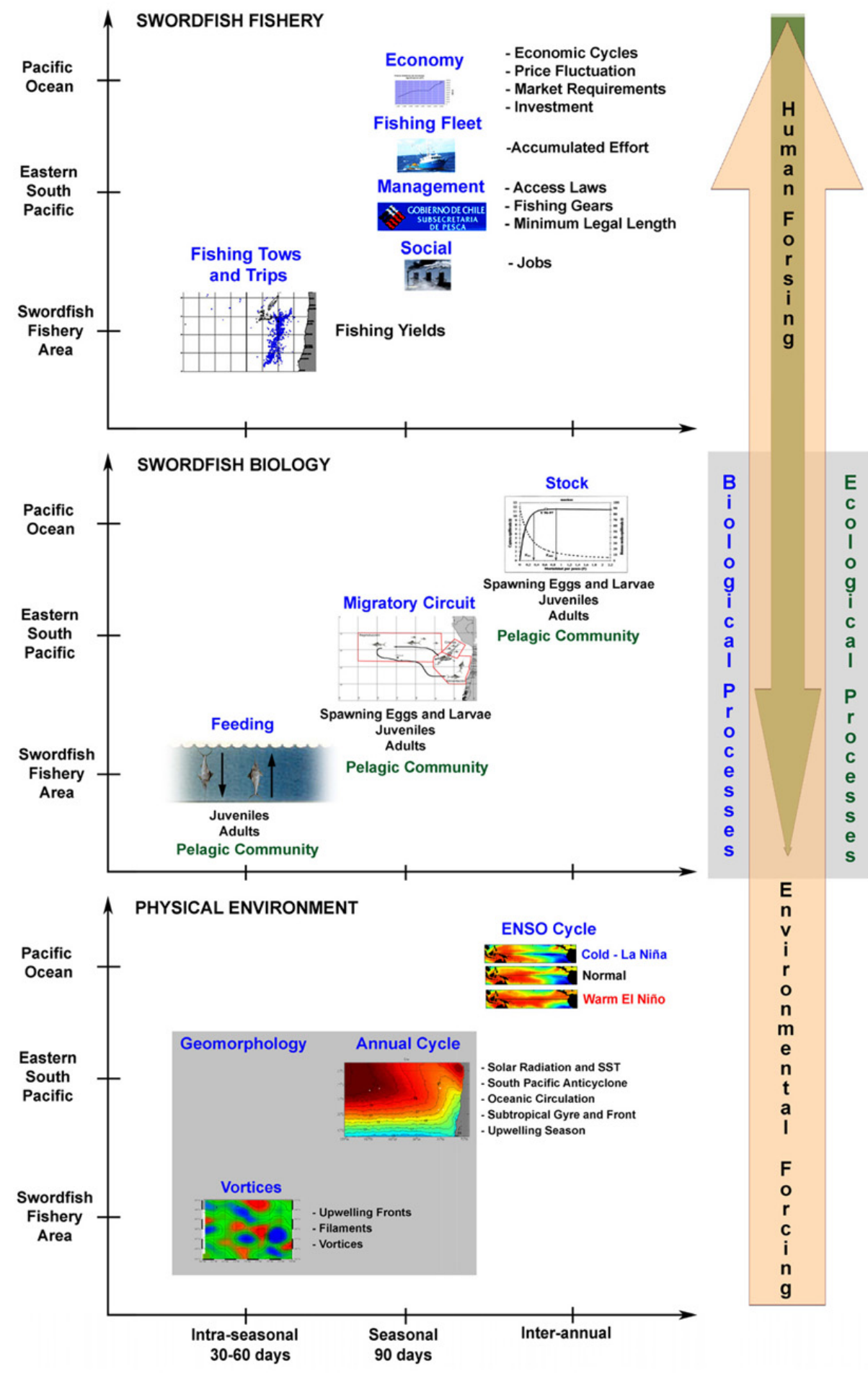

Figure 2

Spatial-temporal conceptual model (3x3), on human (fishing), biological, and physical marine environmental planes, and the processes and forcings of the ecosystem inhabited by swordfish

Modelo conceptual espacio-temporal (3x3), con planos en el ambiente marino físico, biológico y humano (pesquero), junto a los procesos y forzantes del ecosistema habitado por el pez espada 
biology, causing responses at the level of the regional stock.

The biological swordfish processes that are related to changes in the population size can be grouped as either increment by recruitment or reduction by mortality. In this context, some variables can reveal the dynamics of reproduction, natural mortality, and mortality by fishing. On the other hand, the population size can also change due to the immigration and emigration of individuals. Local and larger-scale (annual) displacements are important due to their impact on the availability of the resource for the fishery fleets. The ecological processes refer to interactions between species, including competition and predation, as well as more complex interactions that can result in levels with three or more interacting species. Competition occurs between species from similar trophic niches when their resources are limited; this is associated with the feeding dynamics along thermal fronts that are spatially and temporally limited (Podestá et al. 1993, Olson et al. 1994, Bigelow et al. 1999). It should be noted that swordfish are only top predators as adults; in their earlier developmental stages, they are prey for other pelagic species, including swordfish.

On the interannual scale, associations are established between the swordfish stock, environmental variables, and human factors that consider fluctuations in catches, fishing effort, SST, and phenomena such as El Niño and La Niña. On this scale, the model integrates the swordfish stock in the region, its different developmental stages, the pelagic community, and the general environmental conditions of the Pacific Ocean (Fig. 2).

The model also shows how fluctuations associated with El Niño events are manifested in the ESP and, therefore, in the area of the swordfish fishery off Chile, affecting the seasonal cycle and the intraseasonal dynamics of mesoscale phenomena. On an interannual scale, the physical environment affects the swordfish stock in the region, the seasonality of its migratory circuit, and the feeding of juveniles and adults. The fluctuations of the physical environment that act on the biological plane could extend to the fishery plane, generating variations in the catch rates, which could affect prices and eventually the economic cycles.

On the interannual scale, changes are known to be generated by the ENSO cycles in the ESP, which produce anomalies in the SST and affect the position and intensity of the PA, STG, subtropical Front (STF), and WWD, affecting the intensity and duration of upwelling and the formation of fronts, filaments, and vortexes. In fact, during El Niño events, the advection of higher SST waters increases the temperature anomalies in the eastern Pacific, which are projected towards the ESP, displacing the STG, WWD, and STF southward and nearer the coast. Since swordfish spawning is associated with temperatures over $24^{\circ} \mathrm{C}$, a positive effect is expected on the larval development of the swordfish around Easter Island. On the other hand, during El Niño events and with the new position of the STF, adult swordfish availability and vulnerability increase due to their nearness to the coast, thereby increasing the catch rates (Yáñez et al. 2003b). The higher catches could affect the regional market, decreasing prices due to the increased offer. During La Niña events, the conditions are inverted: temperatures are lower and the STG and STF are displaced to the north and farther offshore. The effects are expected to be the inverse of those of El Niño; particularly, the movement away from the coast should affect the artisanal fishery, which has less autonomy and lower efficiency. The decreased catches generate increased sale prices.

The annual cycle of circulation and solar radiation in the ESP (seasonal scale) affects the duration and spatial distribution of spawning and the spatial distribution, availability, and vulnerability of juveniles and adults in their distribution areas. In the feeding area, associated in part with an area where cold waters are upwelled, productivity increases in the intermediate and high trophic levels that provide prey for top predator fishes such as swordfish (Barbieri et al. 1998). In their migratory context, the adult swordfish are associated with the presence of STF at the beginning of the season (March) near the southern limit of the area $\left(38^{\circ}-42^{\circ} \mathrm{S}\right)$. The fish remain in this sector until November, moving to the north and northwest as the season advances (Espíndola \& Vega 2009). The abiotic conditions of this zone are characterized by SSTs of 16 to $18^{\circ} \mathrm{C}$ and salinities of 34.2 to 34.6, associated with the STG and STF. In the feeding area, the swordfish distribution is associated with greater productivity, with specimens located in areas where the chlorophyll concentrations are greater $\left(0.12-0.2 \mathrm{mg} \mathrm{m}^{-3}\right)$ than those in the oceanic reproduction and rearing areas; the latter is located around Cordillera de Nazca (Yáñez et al. 2009). At the end of October and around $24^{\circ} \mathrm{S}$, a westward migration is undertaken in search of subtropical waters over $24^{\circ} \mathrm{C}$ that will stimulate the reproductive process. After spawning, the juveniles travel to rearing areas that are more appropriate for feeding and survival (Yáñez et al. 2009).

The model relates the effects of mesoscale structures (e.g., oceanic vortexes, upwelling fronts; intraseasonal scale) with the spatial distribution, availability, and vulnerability of juvenile and adult specimens in rearing and feeding zones. Vortexes generate the upwelling of nutrient-rich waters in 
their centres and this, in turn, increases the biological production, transporting and accumulating biomass, and sustaining trophic levels far offshore, including the availability of food items for species such as swordfish. These conditions increase the availability and vulnerability of adult swordfish specimens in the feeding areas. Thus, the increase of mesoscale structures tends to have a positive effect on fishing trips and sets, resulting in higher yields (Espíndola \& Vega 2009).

The general hypothesis of the model indicates that environmental phenomena on diverse scales (interannual, seasonal, intraseasonal) in the Pacific Ocean affect the biological processes of the swordfish in its different developmental phases and the ecological community in its different associated zones. Complementary hypotheses were formulated considering three temporal scales. On the interannual scale, the ENSO events are manifested with positive (El Niño) and negative (La Niña) SST anomalies, affecting the: (1) duration and spatial distribution of spawning around Easter Island; (2) spatial distribution, availability, and vulnerability of juveniles in Cordillera de Nazca; (3) spatial distribution, availability, and vulnerability of adults in feeding areas (where the fishery is carried out), affecting economicsocial aspects such as employment, price, investment, and accumulated effort; and (4) composition, abundance, and distribution of the biotic community of which the swordfish is part.

On the seasonal scale, the annual cycle of solar radiation is manifested through changes in the distribution of the SST isotherms; the displacement of the PA, oceanic circulation (OC), and STF; and the intensity of upwelling, affecting the: (1) duration and spatial distribution of swordfish spawning; (2) spatial distribution, availability, and vulnerability of juveniles; and (3) of adults, which affect aspects such as employment, price, investment, and accumulated effort; and (4) the composition, abundance, and distribution of the fauna community. The fishing effort by foreign fleets affects the local abundance of juveniles in Cordillera de Nazca, whereas the Chilean fleet affects the abundance of adults in the feeding area. Finally, the geomorphology of the Pacific basin off Chile influences the migratory circuit of the swordfish and, therefore, its spatial distribution, availability, and vulnerability.

On the intra-seasonal scale, upwelling fronts and mesoscale structures (e.g., vortexes, filaments), affect the: (1) spatial distribution, availability, and vulnerability of juveniles; (2) spatial distribution, availability, and vulnerability of adults; (3) composition, abundance, and distribution of the community of species; and (4) fleet distribution, affecting the costs and prices.

\section{Comments}

The administration of global fishery activity has moved from a partial, developmentalist vision to an integrated view in which sustainable development is the central objective. This requires switching from monospecies approaches centred on the interaction with the fishing effort to approaches that incorporate biological, interspecies, environmental, and fishery interactions. Although the objectives of ecosystem management are difficult to define, awareness exists that modelling is an important tool for exploring the ecological consequences of fishing and improving understanding of the ecosystem functioning (Olson \& Watters 2003). Thus, our integrated conceptual model explicitly incorporates the effects of exploitation.

Swordfish landings in the ESP show a general tendency to increase, as, following the example of Chile and other South American countries, other countries (e.g. China, Spain, Japan, Korea, France) have become involved in the fishery; this should be monitored closely. This fishery activity is carried out on an existing stock unit in the ESP that has moderately well-defined spawning, growth, recruitment, and feeding areas, based on observations from reproductive activity (Zárate 1997, Donoso et al. 2003, Vega et al. 2009) and fishery characteristics, including fleet distribution and seasonal patterns in catch, CPUE and size composition (Donoso et al. 2003, Barría et al. 2006, Espíndola \& Vega 2009, Vega et al. 2009, Yáñez et al. 2004, 2006, 2009). This information allows to hypothesize an annual migratory circuit off Chile, where swordfish changes its habitat according to its stage of development and nutritional needs.

Because of the wide geographic distribution of swordfish, its life history, and its migratory activity, it is necessary to include egg-larva, juvenile, and adult stages in the conceptual model; these stages are distributed geographically in reproduction, rearing, and adult feeding zones. The model conjointly incorporates environmental, biological, ecological, and fishery processes, as defined on planes of three spatial (Pacific Ocean, ESP, fishery area) and three temporal (interannual, seasonal, intraseasonal) scales.

The spatial distribution of the swordfish fishery in the ESP suggests that the submarine mountains influence the distribution and migration of the resource in the region. The underwater range uniting Easter Island the Nazca Ridge is populated mainly by juveniles (Yánez et al. 2004, 2006), whereas adults dominate the range connecting central Chile and Easter Island; these specimens are caught by Chile's industrial longline fleet (Barría et al. 2005, 2006, Espíndola \& Vega 2009). Nonetheless, little in situ data is available that shows the consistency of these ecological associations in the South Pacific. 
The integrated vision provided by this conceptual model, without detracting from current operational fishery research, proposes the working dimensions necessary for allowing the development of integrated fishery research and management, considering the ecosystem approach proposed by the FAO (2003).

Finally, it should be noted that the available information and data bases, as well as the proposed conceptual model and hypotheses, allow moving on to the next step in swordfish research in the ESP: establishing and defining methodologies to validate cause-effect relationships.

\section{Acknowledgments}

The authors thank Patricio Barría, Miguel Donoso, and Claudio Bernal for their contributions to the literature review. We also thank Fondo de Investigación Pesquera since this study was generated within the framework of FIP Project 2005-28 'Integración del conocimiento sobre el recurso pez espada en el Océano Pacífico sudeste en una perspectiva ecosistémica: Fase I'. We also appreciate very sincerely the anonymous reviewer for the relevant suggestions.

\section{Literature cited}

Acuña E, JC Villaroel \& R Grau. 2002. Fauna íctica asociada a la pesquería de pez espada (Xiphias gladius). Gayana 66(2): 263-267.

Alvarado Bremer JR, MG Hinton \& TW Greig. 2004. Population structure of swordfish in the Pacific Ocean: A review of genetic studies based on the analyses of nuclear and mitochondrial data. Interim Scientific Committee for Tuna and Tuna-Like Species in the North Pacific Ocean (ISC), 26 January-4 February 2004, Honolulu, Hawaii, USA, Working Paper ISC/04/SWO-WG/03, 8 pp.

Alvarado Bremer JR, MG Hinton \& TW Greig. 2006. Evidence of spatial genetic heterogeneity in Pacific swordfish (Xiphias gladius L.) revealed by the analysis of ldh-A sequences. Bulletin of Marine Science 79(3): 493503.

Bakun A. 1996. Patterns in the Ocean: Ocean Processes and Marine Population Dynamics. University of California Sea Grant, San Diego, California, USA, in cooperation with Centro de Investigaciones Biológicas de Noroeste, La Paz, Baja California Sur, México, 323 pp.

Bakun A. 2006. Fronts and eddies as key structures in the habitat of marine fish larvae: opportunity, adaptive response and competitive advantage. Scientia Marina 70(Suppl. 2): 105-122.

Bakun A \& C Nelson. 1991. The seasonal cycle of wind-stress curl in subtropical eastern boundary current regions. Journal of Physical Oceanography 21(12): 1815-1834.
Barbieri MA, E Yáñez L Aríz \& A González. 1990. La pesquería del pez espada: tendencias y perspectivas. In: Barbieri MA (ed). Perspectivas de la Actividad Pesquera en Chile, pp. 195-214. Escuela de Ciencias del Mar, Pontificia Universidad Católica de Valparaíso, Valparaíso.

Barbieri MA, C Canales, V Correa, M Donoso, A González, B Leiva, A Montiel \& E Yáñez. 1998. Development and present state of the swordfish, Xiphias gladius, fishery in Chile. In: Barret I, O Sosa-Nishizaki \& N Bartoo (eds). Biology and fisheries of swordfish, Xiphias gladius. NOAA Technical Report NMFS 142: 1-10.

Barría P, M Donoso, J Azócar, F Cerna, M Nilo, E Palta, H Miranda \& V Catasti. 2005. Programa seguimiento del estado de situación de las principales pesquerías nacionales. Investigación situación pesquerías de recursos altamente migratorios, 2004. Informe final Fase II. IFOPSUBPESCA, pp. 1-171.

Barría P, M Donoso, J Azócar, F Cerna, H Miranda \& V Catasti. 2006. Programa seguimiento del estado de situación de las principales pesquerías nacionales. Investigación Situación Pesquerías de Recursos Altamente Migratorios, 2005. Informe final. IFOP-SUBPESCA, pp. $1-140$.

Beckett J. 1974. Biology of swordfish, Xiphias gladius, in the northwest Atlantic Ocean. In: Shomura R \& F Williams (eds). International Billfish Symposium, Part 2: Review and contributed papers. NOAA Technical Report NMFS SSRF 675: 103-106.

Bello M, MA Barbieri, S Salinas \& L Soto. 2004. Surgencia costera en la zona central de Chile, durante el ciclo El NiñoLa Niña 1997-1999. In: Avaria S, J Carrasco, J Rutllant \& E Yañez (eds). El Niño-La Niña 1997-2000: Sus Efectos en Chile, pp. 77-94. Comité Oceanográfico Nacional, Valparaíso.

Bernal P, F Robles \& O Rojas. 1983. Variabilidad física y biológica en la región meridional del sistema de corrientes Perú-Chile. FAO Fisheries Report 291: 683-711.

Bernal P. 1990. La oceanografía del sistema de corrientes de Chile-Perú en relación a las pesquerías pelágicas. In: Barbieri MA (ed). Perspectivas de la actividad pesquera en Chile, pp. 35-48. Escuela de Ciencias del Mar, Pontificia Universidad Católica de Valparaíso, Valparaíso.

Bertrand A, M Segura, M Gutiérrez \& L Vásquez. 2004. From small-scale habitat loopholes to decadal cycles: a habitat-based hypothesis explaining fluctuations in pelagic populations off Peru. Fish and Fisheries 5: 296-316.

Bigelow H \& W Schroeder. 1953. Fishes of the Gulf of Maine. Fishery Bulletin 53(74): 1-577.

Bigelow KA, CH Boggs \& X He. 1999. Environmental effects on swordfish and blue shark catch rates in the US North Pacific longline fishery. Fisheries Oceanography 8: 178198.

Blanco JL, AC Thomas, ME Carr \& PT Strub. 2001. Seasonal climatology of hidrographic conditions in the 
upwelling region off Northern Chile. Journal of Geophysical Research 1006(C6): 11,451-11,467.

Blanco JL, ME Carr, AC Thomas \& PT Strub. 2002. Hydrographic conditions off Northern Chile during the 1996-1998 La Niña and El Niño events. Journal of Geophysical Research 107(C3): 1-19

Castillo K, C Ibáñez, C González \& J Chong. 2007. Dieta del pez espada Xiphias gladius Linnaeus, 1758 en distintas zonas de pesca frente a Chile central durante el otoño de 2004. Revista de Biología Marina y Oceanografía 42(2): 149-156.

Chaigneau A\& O Pizarro. 2005. Surface circulation and fronts of the South Pacific Ocean, east of $120^{\circ} \mathrm{W}$. Geophysical Research Letters 32(8): L08605

Chancollon O, C Pusineri \& V Ridoux. 2006. Food and feeding ecology of Northeast Atlantic swordfish (Xiphias gladius) off the Bay of Biscay. ICES Journal of Marine Science 63: 1075-1085.

Chavez FP, JT Pennington, CG Castro, JP Ryan, RP Michisaki, B Schlining, P Walz, KR Buck, A McFadyen \& CA Collins. 2002. Biological and chemical consequences of the 1997-1998 El Niño in central California waters. Progress in Oceanography 54: 205-232.

Chavez, FP, J Ryan, SE Lluch-Cota \& M Niquen. 2003. From anchovies to sardines and back: multidecadal change in the Pacific Ocean. Science 299: 217-221.

Daneri G, V Dellarossa, R Quiñones, B Jacob, P Montero \& O Ulloa. 2000. Primary production and community respiration in the Humboldt Current system off Chile and associated oceanic areas. Marine Ecology Progress Series 197: 43-51.

De Metrio G, P Megalofonou, S Tselas \& N Tsimenides. 1989. Fishery and biology of the swordfish Xiphias gladius in the Greek waters. FAO Fisheries Report 412: 135-140.

Donoso M, R Vega, V Catasti, G Claramunt, G Herrera, C Oyarzún, M Braun, H Reyes \& S Letelier. 2003. Biología reproductiva y área de desove del pez espada en el Pacífico Sur Oriental. Informes Técnicos FIP-IT/2000-11: 1-105.

Espíndola F \& R Vega. 2009 (in press). Identification of the spatial-temporal distribution pattern of swordfish (Xiphias gladius) in the eastern South Pacific. Latin American Journal of Aquatic Research 37(1).

FAO. 2003. The ecosystem approach to fisheries. Technical Guidelines for Responsible Fisheries 4(Suppl. 2): 1-112.

FAO. 2007. The State of World Fisheries and Aquaculture 2006, 180 pp. FAO Fisheries and Aquaculture Department, Rome.

Grall C, DP de Sylva \& ED Houde. 1983. Distribution, relative abundance, and seasonality of swordfish larvae. Transactions of the American Fisheries Society 112: 235246.

Haury LR, JA McGown \& PH Wiebe. 1978. Patterns and processes in the time-space scales of plankton distributions. In: Stelle JH (ed). Spatial Patterns in Plankton Communities, pp. 277-327. Plenum Press, New York.
Hernández-García V. 1995. The diet of the swordfish Xiphias gladius Linnaeus 1758 in the central east Atlantic, with emphasis on the role of cephalopods. Fishery Bulletin 93: 403-411.

Hinton MG, WH Bayliff \& JM Suter. 2005. Assessment of swordfish in the eastern Pacific Ocean. Inter-American Tropical Tuna Commission, Stock Assessment Report 5: 291-326.

Hormazábal S, G Shaffer \& O Pizarro. 2002. Tropical Pacific control of intraseasonal oscillations off Chile by way of oceanic and atmospheric pathways. Geophysical Research Letters 29(6): 1081.

Hormazábal S, G Shaffer, J Letelier \& O Ulloa. 2001. Local and remote forcing of the sea temperature in the coastal upwelling system off Chile. Journal of Geophysical Research 106 (C8): 16657-16671.

Ibáñez C, C González \& L Cubillos. 2004. Dieta del pez espada Xiphias gladius Linnaeus, 1758 en aguas oceánicas de Chile central en invierno de 2003. Investigaciones Marinas, Valparaíso 32(2): 113-120.

Kume S \& J Joseph. 1969. Size composition and sexual maturity of billfishes caught by the Japanese longline fishery in the eastern Pacific Ocean east of $130^{\circ} \mathrm{W}$. Bulletin of the National Research Institute of Far Seas Fisheries 2: 115162.

Leth O \& G Shaffer. 2001. A numerical study of seasonal variability in the circulation off central Chile. Journal of Geophysical Research 106 (C10): 22229-22248.

Mann KH \& JRN Lazier. 1996. Dynamics of marine ecosystems: biological-physical interactions in the oceans, 394 pp. Blackwell Science, Boston.

Maturana J, M Bello \& M Manley. 2004. Antecedentes históricos y descripción del fenómeno El Niño, Oscilación del Sur. In: Avaria S, J Carrasco, J Rutllant, \& E Yáñez (eds). El Niño-La Niña 1997-2000, pp. 13-27. Comité Oceanográfico Nacional, Valparaíso.

Matsumoto WM \& TK Kazama. 1974. Ocurrence of young billfishes in the central and Pacific Ocean. NOAA Technical Report NMFS SSRF 675(2): 238-251.

Maury O \& P Lehodey (eds). 2005. Climate impacts on oceanic top predators (CLIOTOP). Science Plan and Implementation Strategy. GLOBEC Report 18: 1-42.

Moreira F. 1990. Food of the swordfish, Xiphias gladius Linnaeus, 1758, off the Portuguese coast. Journal of Fish Biology 36: 623-624.

Nishikawa Y, M Honma, S Ueyanagi \& S Kikawa. 1985. Average distribution of larvae of oceanic species of scombrid fishes, 1956-1981. Far Seas Fisheries Research Laboratory, Shimizu, S Series 12, 99 pp.

Oliver C. 1943. Catálogo de los peces marinos del litoral de Concepción y Arauco. Boletín Sociedad de Biología de Concepción 17: 75-126.

Olson DB, GL Hitchcock, AJ Mariano, CJ Ashjian, G Peng, RW Nero \& GP Podestá. 1994. Life on the edge: marine life and fronts. Oceanography 7: 52-60. 
Olson RJ \& GM Watters. 2003. A model of the pelagic ecosystem in the Eastern Tropical Pacific Ocean. InterAmerican Tropical Tuna Commission Bulletin 22(3): 133217.

Palko RJ, GL Beardsley \& WJ Richards. 1981. Synopsis of the biology of the swordfish Xiphias gladius Linnaeus. FAO Fisheries Synopsis 127: 1-21.

Perry RI, JA Boutillier \& MGG Foreman. 2000. Environmental influences on the availability of smooth pink shrimp, Pandalus jordani, to commercial fishing gear off Vancouver Island, Canada. Fisheries Oceanography 9: 5061.

Perry RI \& RE Ommer. 2003. Scale issues in marine ecosystems and human interactions. Fisheries Oceanography 12: 513-522.

Podestá GP, JA Browder \& JJ Hoey. 1993. Exploring the association between swordfish catch rates and thermal fronts on U.S. longline grounds in the western North Atlantic. Continental Shelf Research 13: 253-277.

Reeb CA, L Arcangeli \& BA Block. 2000. Structure and migration corridors in Pacific populations of the swordfish Xiphias gladius, as inferred through analyses of mitochondrial DNA. Marine Biology 136: 1123-1131.

Rojas R \& N Silva. 1996. Atlas oceanográfico de Chile $\left(18^{\circ} 21^{\prime} \mathrm{S}-50^{\circ} 00^{\prime} \mathrm{S}\right)$. Volumen I, $234 \mathrm{pp}$. Servicio Hidrográfico y Oceanográfico de la Armada, Valparaíso.

Sakagawa GT. 1989. Trends in fisheries for swordfish in the Pacific Ocean. In: Stroud RH (ed). Planning the future of billfishes: Research and management in the 90s and beyond. Proceedings of the Second International Billfish Symposium, Kailua-Kona, Hawaii, August 1-5 1988. National Coalition for Marine Conservation, Savannah, Part I: $61-80$.

Sakagawa GT \& R Bell. 1980. Swordfish Xiphias gladius. In: Shomura RS (ed). Report of the Billfish Stock Assessment Workshop, Pacific Resources. NOAA Technical Memorandum NMFS-SWFC 5: 1-50.

Scott WB \& SN Tibbo. 1968. Food and feeding habits of swordfish, Xiphias gladius, in the western North Atlantic. Proceeding of the International Billfish Symposium, Hawaii, Part 2: 138-141.

Sedberry GR \& JK Loefer. 2001. Satellite telemetry tracking of swordfish, Xiphias gladius, off the eastern United States. Marine Biology 139(2): 355-360.

Seki MP, JJ Polovina, DR Kobayashi, RR Bidigare \& GT Mitchum. 2002. An oceanographic characterization of swordfish (Xiphias gladius) longline fishing grounds in the springtime subtropical North Pacific. Fisheries Oceanography 11(5): 251-266.

SERNAPESCA. 1978-2007. Anuarios Estadísticos de Pesca. Servicio Nacional de Pesca, Ministerio de Economía, Valparaíso.

Shaffer G, S Hormazábal, O Pizarro \& S Salinas. 1999. Seasonal and interannual variability of currents and temperature off central Chile. Journal of Geophysical Research 104(C12): 29951-29961.

Silva N. 1983. Masas de agua y circulación de la región norte de Chile. Ciencia y Tecnología del Mar 7: 47-84.

Silva N \& S Neshyba. 1979. Masas de agua y circulación geostrófica frente a la costa de Chile austral. Instituto Antártico Chileno, Serie Científica 25: 5-32.

Smith W \& D Sandwell. 1997. Global sea floor topography from satellite altimetry and ship depth soundings. Science 277: 1956-1962.

Sosa O \& M Shimizu. 1991. Stock unit of the Pacific swordfish inferred from spatial and temporal CPUE trends in the Japanese tuna longline fishery. Bulletin of the National Research Institute of Far Seas Fisheries 28: 75-90.

Stillwell C \& N Kohler. 1985. Food and feeding ecology of the swordfish in the eastern Atlantic with estimates of daily ration. Marine Ecology Progress Series 22: 239-247.

Stramma L, R Peterson \& M Tomczak. 1995. The south Pacific current. Journal of Physical Oceanography 25: 7791.

Strub P, J Mesías, V Montecino, J Rutlland \& S Salinas. 1998. Coastal ocean circulation off western South America. In: Robinson AR \& KH Brink (eds). The sea: The global coastal ocean, regional studies and synthesis, pp. 273-313. John Wiley and Sons, New York.

Suzuki Z \& N Miyabe. 1990. Heterogeneous sex ratio of Atlantic swordfish and implication to cohort analyses. ICCAT Collective Volume of Scientific Papers 32(2): 377386.

Tibbo S, L Day \& W Doucet. 1961. The swordfish (Xiphias gladius L.) its life history and economic importance in the Northwest Atlantic. Bulletin of the Fisheries Research Board of Canada 130: 1-47.

Tomczak M \& JS Godfrey. 2001. The Pacific Ocean. Chapter 8. In: Regional Oceanography: An Introduction. www.es.flinders.edu.au/ mattom/regoc/pdffiles/colour/ single/08P-Pacific.pdf.

Vega R, R Licandeo, G Rosson \& E Yáñez. 2009 (in press). Species catch composition, length structure and reproductive indices of swordfish (Xiphias gladius) at Easter Island zone. Latin American Journal of Aquatic Research 37(1).

Ward P, J Porter \& S Elscot. 2000. Broadbill swordfish: status of established fisheries and lessons for developing fisheries. Fish and Fisheries 1: 317-336.

Weidner D \& J Serrano. 1997. World swordfish fisheries: An analysis of swordfish fisheries, market trends, and trade patterns. NOAA Technical Memorandum 4: 1- 843.

Yáñez E, C Silva, MA Barbieri \& K Nieto. 1996. Pesquería artesanal de pez espada y temperatura superficial del mar registrada con satélites NOAA en Chile central. Investigaciones Marinas, Valparaíso 24: 131-144.

Yáñez E, MA Barbieri, F Ponce, M Donoso, C Canales, $R$ Toro \& J Acevedo. 2003a. Monitoreo y evaluación de la pesquería chilena de pez espada. In: Yánez E (ed). Actividad 
Pesquera y de Acuicultura en Chile, pp. 143-156. Escuela de Ciencias del Mar, Pontificia Universidad Católica de Valparaíso, Valparaíso.

Yáñez E, MA Barbieri \& C Silva. 2003b. Fluctuaciones ambientales de baja frecuencia y principales pesquerías pelágicas chilenas. In: Yánez E (ed). Actividad Pesquera y de Acuicultura en Chile, pp. 109-121. Escuela de Ciencias del Mar, Pontificia Universidad Católica de Valparaíso, Valparaíso.

Yáñez E, C Silva, J Marabolí, F Gómez, N Silva, E Morales, A Bertrand, J Campalans, A Gamonal, J Chong, P Rojas, B Menares \& JI Sepúlveda. 2004. Caracterización ecológica y pesquera de la Cordillera de Nazca como área de crianza del pez espada. Informes Técnicos FIP-IT/ 200204: 1-388.

Yáñez E, C Silva, A Órdenes, F Gómez, A Valdenegro, $N$ Silva, S Hormazábal, A Montecinos, L Cubillos, F Espíndola, O Pizarro \& JR Cañón. 2005. Análisis integrado histórico ambiente-recursos, I-II regiones. Informes Técnicos FIP-IT/ 2003-33: 1-478.
Yáñez E, C Silva, N Silva, A Ordenes, F Leiva, P Rojas, J Chong, J Campalans, S Palma, G Claramunt, C Oyarzún, R Meléndez \& R Vega. 2006. Caracterización ecológica y pesquera de Cordillera de Nazca como área de crianza del pez espada. Fase II. Informes Técnicos FIP-IT/ 2004 -34: 1-236.

Yáñez E, S Hormazábal, C Silva, A Montecinos, A Órdenes, L Cubillos, F Gómez \& A Valdenegro. 2007. Ecosystem indicators and an integrated conceptual model in the southeast Pacific. GLOBEC International Newsletter 13(1): 4142.

Yáñez E, C Silva, MA Barbieri, A Órdenes \& R Vega. 2009 (in press). Environmental conditions associated with swordfish size compositions and catches off the Chilean coast. Latin American Journal of Aquatic Research 37(1).

Zárate P. 1997. Biología reproductiva del pez espada, Xiphias gladius (Linnaeus 1758), en aguas chilenas. Tesis de Biología Marina, Facultad de Ciencias del Mar, Universidad Católica del Norte, Coquimbo, 111 pp.

Recibido el 30 de septiembre de 2008 y aceptado el 24 de noviembre de 2008 